\title{
Reconsideration on Foreign Trade Relations in Ancient China --Centered on the Silk Road and Tribute System
}

\author{
Wang Zijun \\ Nanjing Foreign Language School
}

Keywords: Foreign Trade; Silk Road; Tributary System; Networks.

\begin{abstract}
Under the new situation of international trade competition, it is very important to re-examine China's trade policies and foreign relations with other economic forces in East Asia from a historical perspective. It is also possible to re-analysis the Ancient Silk Road and the Tribute System, and make some new explanation. This paper holds that the construction and expansion of the foreign trade networks in ancient China was not only closely relative to the changes and development of domestic strength, but also tightly relevant to the cooperation, comparison and interaction with other countries, especially those surrounding China in East Asia. The ancient trade relations also reveal the irregular fluctuation pattern from a long period of time.
\end{abstract}

\section{Introduction}

In 2013, China formally introduced the concept of the 'The Belt and Road', which takes the Silk Road economic belt and the 21st century maritime Silk Road as an important policy for foreign exchanges, economic development and opening up a new situation. This is not only the embodiment of China's economic development in the new era, but also the embodiment of its new economic development needs and aspirations. It means that China needs a wider world, a bigger market and more partners. On the basis of deepening Sino-foreign cooperation, China also needs to change domestic economic structure, to turn the development pattern and to enhance China's strength and influence. However, when we observe and comment on The Belt and Road's policies, functions and influences, we can't avoid rethinking and examining two important historical topics: Ancient Chinese Silk Road and tribute system.

As an academic concept, the Silk Road, named after the German scholar Friedrich Von Richthoen in 1877, originated from his paper about the travel in East Asia. He believed that the Silk Road was a road of foreign exchange that had been integrated with politics, economy and culture since Zhang Qian's departure from the western region. It is also the only way to the world for China, since the east land was separated before the rise of the Tang and Song maritime activities. This led to a boom in research on the Silk Road in modern times, from China to Asia to the world as a whole, from academia to national government, from economics to politics. It is a reflection of reality: not only the real academic interests and research, but also the realities and changes of international economic, political and cultural relations.

In the 1960s and 1970s, Japan launched a Silk Road craze. Japanese scholar Nagasawa Kazutoshi believed that the silk road was not only the main axis of the study on the arteries and world history at both ends of Asia and Africa, but also the starting point of the world's major cultures. The study of the Silk Road also promoted the development of Toponymy, ethnology, literature, art and natural science. At the same time, however, some people thought that the silk road-centered research would hinder the development of the study of the history of the various ethnic groups in central Asia, thus ignoring the characteristics of each ethnic region. In the 1980s, the study of the maritime Silk Road became an upsurge, in addition to land, the Maritime Silk Road was put forward, which was formed before the Tang and song Dynasties and very prosperous in the Yuan and Ming Dynasties. From the shipping industry to the shipbuilding industry, from the domestic to East Asian countries and even the world, the Maritime Silk Road made the ancient Chinese production technology spread, linking the major civilizations.

The Silk Road corresponds to the study of the tribute system, which also has continued and has new explanations. Chinese scholars used to discuss the system and structure of tribute from the 
perspective of the Chinese standard, while He Fangchuan and Chen Shangsheng thought that from the Han Dynasty to the late Qing Dynasty, the 'Hua-Yi System' was formed between the Chinese empire and the surrounding countries. From the angle of Chinese standard, Huang Zhilian thought that ancient China and its surrounding countries formed the system of rules and regulations of the imperial court. Western scholars tended to interpret it from the perspective of "the other" or the perspective of the west, with John King Fairbank as the representative, believing that the tribute system was a Chinese-centered and Chinese-foreign order that embodies China's superiority. But by the end of the empire, loose and unstable tributaries had failed to resist the treaty system of the western colonists. From the perspective of the Asian economic circle, Takeshi Hamashita looked for the links within Asia and the driving force for Asian development, he found that the Asian economic circle was a kind of central relationship of polygon and intersection.

When thinking about the current situation, we could find some clues form the past. Looking back to the Silk Road and Tribute System from both a realistic and historical perspective, it would be significant for us to understand China, East Asia, the Asia-Pacific (or Indo-Pacific), and the diversified relations..

\section{The Silk Road: China's Exploration of the World}

In the pre-Qin period, the communication channels between east and west connecting China and inner Asian countries already existed, but the large-scale and organized development of foreign trade channels was in the early Han Dynasty. The western Han Dynasty was faced with internal and external difficulties, and there was a lot to be done. By the time of emperor Wu of the Han Dynasty, the national strength was unprecedented and strong, and the internal political and economic stability of the country. Therefore, emperor Wu of the Han Dynasty could put his eyes on the threat of the Huns(XiongNu). To connect with Kushan Empire(Darouzhi) to resist with the Huns, Emperor Wu of Han sent Zhang Qian to the western region to open a new road and build the connection. After the Han Dynasty won the battle against the Huns, military victory was won against Loulan, Gushu and Dayuan in the western region, which ensured the smooth road of the Han Dynasty to the west, and the transportation between the east and the west was greatly expanding.

Several centuries later, the emperor of the Eastern Han Dynasty sent Ban Chao and Ban Gu to the western regions again to reconnect with many countries in the western regions, resulting in connecting with more than 80 countries, so that the western region could maintain long-term trade with the Han Dynasty. Even as far away as the great Roman to send envoys to the Han Dynasty through the silk road, to contribute ivory, horn, hawthorn and other things, in exchange for Chinese silk.

With the dual roles of military and economy, Dunhuang became the most important spot of the Silk Road between China and the Inner-Asia. The transportations and networks were divided into two parts, the north and south, south by the inland, north by Shule (Kashgar) to Dayuan (now Fergana, Russia), Sogdiana, and then to India and western Asia. Han Dynasty also often sent envoys and caravan to the west, the caravan could even up to hundreds of people. This had contributed greatly to the promotion of exchanges between various nationalities and between Han Dynasty and neighboring countries. The development and expansion of the Silk Road between the two Han Dynasties were the results of the western Han Dynasty's active exploration on the basis of its internal and external pressure.

During the period of the Three Kingdoms (SanGuo), countries in the western regions, such as Parthia, Dayuan and Sogdiana, continued to trade by land. The merchants of the great Roman had come to Kingdom of $\mathrm{Wu}$, ruled by Sun Quan, to introduce the geography and customs. After the Rome was divided into two parts, the Eastern Roman Empire controlled the transportation between the east and west, and the trade with China. Chinese exported silk, copper, iron, pottery and fur, and imported commodities such as glassware, medicines, dyes, hardware, horses and jewelry. During that time, the word "Gong” (Tribute) came out in the historical records.

During the same period, China's maritime trade also developed rapidly. According to western historical records, by the $5^{\text {th }} \mathrm{BC}$, India had trade with the South China Sea. According to HanShu, 
seagoers took sea voyage from the South China Sea cities such as Rinan, Hepu, Xuwen, as far as southern India's yellow branch. According to The Debates on Salt and Iron (YanTieLun), China carried cargo to the South China Sea for the exchange of horn, jewelry and other treasures. Japan sent envoys to Luoyang through the Korean Peninsula, the state of Wei gave many brocade and jewelry. In HanShu, records of many of astrology about the sea star were related to navigation, which also became a specialized knowledge.

In the Northern and Southern Dynasties, the Northern Dynasties were overland, with Luoyang and Guangzhou as the centers in north and south. During this period, foreign trade exchanges included not only the commodity trade, but also the slave trades on many historical books and the Kunlun slave records. At that time the books recorded the geographical transportation's work, many more than 100 kinds, and fully reflected frequent the economic exchanges and the prosperity.

During the Tang Dynasty, foreign trade flourished. As the economic center, Chang'an led to the western region, central Asia, Afghanistan, Nepal, and India. All over the commercial road with a shelter for traders to rest, could be seen at the time of trade specialization and scale. China's exports have increased, with the exception of silk, porcelain, paper, bronze, iron, tea and so on, also became a major transaction. After that, paper making craft, iron smelting and silkworm rearing technology also spread to the west.

China's advanced shipping technology has promoted the rapid development of trade between China and foreign countries. In 714, the government set up a department of marketing, Bureau for Foreign Shipping (Shibo Department), specializing in maritime trade. The task of the department was to collect import and export duties, inspect the vessels for carrying contraband, keep the imported goods, buy the government counterfeit goods and so on. Bureau for Foreign Shipping had the nature of Customs, which continued to exist during Song, Yuan, Ming and other Dynasties

In the Song Dynasty, after the war of the Five Dynasties and Ten Kingdoms, the production was restored and developed, the compass was used in navigation, and maritime trade was further flourishing. There were more than 50 countries trading with China. In the early days of the northern Song Dynasty, the rulers thought that the benefits of Shibo department would help the state to use the method of rewarding foreign trade by granting official posts and arranging living. Guangzhou and Quanzhou were equipped with production workshop; the largest number of foreign businessmen is Stag-gzig. The Stag-gzig was the Arab empire, during which the Arab merchants controlled the trade between east and west. The two Song governments set up the southeast coast of the city in charge of foreign trade, city secretary of the city of Guangzhou, Wyoming, Hangzhou, Zhangzhou, Mizhou and so on. Mizhou shipping was the transportation to Liaodong, North Korea and Japan, the rest of which were all in the South China Sea and the Indian Ocean. At the end of Shaoxing, Guangzhou and Quanzhou alone earned 2 million, which accounted for one twentieth of the annual revenue of the song Dynasty.

In Yuan Dynasty, land and sea road transportation were more developed and foreign trade increased rapidly. In order to safeguard the interests of the ruling class of Mongolia, the Yuan government adopted the policy of monopolizing foreign trade by government officials, which means that officials should own the boats and buy the goods. If a person was elected to trade goods, he would receive a rate of ten cents, and the official would take seventy percents of the goods. Its main purpose was to increase government revenue and prohibit private foreign trade. But out of the temptation of huge interests, private businessmen into the sea phenomenon could not be put an end to. By the fourteenth year of the Yuan, the Yuan Dynasty encouraged private businesses to go abroad for trade and returned to China the following year.

It 's proved that from the Han Dynasty to the Yuan Dynasty, the two foreign trade routes, land and sea, have had very important impacts. There is a strong interest in exploring and expanding the trade path outwards and, with military, political and diplomatic assistance is active. But it is not enough to analyze the foreign trade of ancient China from the angle of economy. The formation and development of tribute trade system is another angle of analysis. 


\section{Tribute System: From the Periphery to China}

Ge Zhaoguang puts forward a view of China from the periphery to China, to go beyond the limits of China and to observe and understand Asia better. The tribute system has deeper political implications than the Silk Road. In a broad sense, the tribute system was a comprehensive system of political, economic and cultural order centered on ancient China and radiating from east Asia, southeast Asia and central Asia. In the name of the surrounding vassal state to the central plains Dynasty, others paid tribute to the central plains Dynasty, through the system of military service, the system of custody and other systems. In terms of economic and trade, in addition to official tributes and titles, there were a large number of folk exchanges and exchanges, with tribute trade as a link. In ancient times, China had close economic ties with its neighbors.

As early as the Shang Dynasty in China, the rulers have established a system of internal and external ruling system, in which the monarch of the central plains of China is the Co-owner of external people. The monarch established an administrative organization in the central part of the kingdom (internal service) for direct administration. Outside the central area, the monarch ruled the people by controlling and educating the local leaders, making them accept the titles and the orders, forming the interactions with each other between the interior and the exterior.

After the unification of the central plains by the Qin Dynasty in 221 BC, a centralized state was established. At that time, the whole of China's surrounding areas, including the whole of East Asia and Southeast Asia, apart from the Huns, there was no power to compete with the Qin Dynasty. In the western Han Dynasty, after the Han emperor defeated the Huns and opened the western region, there was no regime known to rival the Han Dynasty, and the tribute trade system centered on China was established. In the system of tribute in this period, the central plains regime and other countries mainly sealed the relationship. That was, all foreign countries needed to take the initiative to recognize the central plains regime's Co-dominance status, and by virtue of the central government to obtain the legitimacy of the rule.

After the Han Dynasty, the central plains political situation was turbulent. After the disintegration of the western Jin Dynasty, the nomadic peoples of the north entered the central plains in large numbers. When the Tang Dynasty collapsed, the tribute system also dropped. The Song Dynasty was weak and unable to rebuild the system of tribute, and the whole system of tribute fell into chaos. During this period, the central plains regime often adopted the policy of restraint to replace the original system of entrustment; the most important feature was that the gift was not only the royal, but the same official position as the immediate officials.

In Tang Dynasty, there were three kinds of detention system. One was the custody of the state and county established in the area under the influence of the military forces of the Tang Dynasty. And symbolic tribute, but with some responsibilities, such as loyalty to the central plains government, non-annexation of other detention units and the mainland state and county, as well as the provision of troops as required, etc. In fact, the central plains regime regarded it as a part of the territory, and the instruments were forgiven. The so-called inner dependent countries, such as the Bohai, Shule, south Carolina, and Khitan, were generally designated as governor or king of the county and had their own territory. However, the political legitimacy of their leaders came from the entrustment of the central plains government, and they could not be autonomous. The central plains government regarded them as ministers. One was the so-called enemy state and the country of the great domain, such as the Tibetan, the Uyghur and the Japanese, although they might also be given titles, many of them were in recognition of the reality. The legality of the chief's notification did not depend on the enclosures of the central plains regime. After the Song Dynasty, it further strengthened the control of the state and county in the first situation. Besides the tribal leaders, the central plains government appointed supervisory officials, which gradually evolved into the Tusi System in the Yuan Dynasty. In fact, it was included in the territory of the central plains regime.

The foreign trade of the Ming Dynasty adopted strict tribute trade, which is, only allowed the official trade between the two countries, and private vessels were not allowed to travel. The tribute trades were strict with regulations on the tribute countries, routes, ports, number of vessels and types of tributes. The government gave official proof to the tribute countries and stipulated the 
number of years and numbers of foreign ships coming to China. The foreign trade of the Ming Dynasty adopted strict tribute trade that only allowed the official trade between the two countries, and private vessels were not allowed to travel. In the early 15th century, with Zheng He's powerful treasure fleet cruising the Indian Ocean and Yongle Emperor's mopping up the northern Mongolian forces, the tribute system reached its peak. Under the coercion of the Ming army and navy and the lure of the thick-headed policy, the number of countries and tribes paying tribute to the Ming government once reached 65. During this period, in addition to the direct contacts with the Ming Dynasty in Korea, Vietnam, Myanmar and other foreign countries, under the guidance of thick and thin, some other countries paid tribute to the Ming Dynasty. Gradually it evolved into a kind of trade, especially the Sea Forbidden in the middle and late Ming Dynasty, making tribute the only channel for these countries to trade with China.

In 1644, the Qing Dynasty established its rule over the mainland of China and retained the Ming Dynasty tribute system, only to ask countries to pay back the Ming Dynasty and receive the Qing Dynasty. The Qing Dynasty clearly divided the exchanges with the surrounding tribes into the jurisdiction of the court and the Ministry of rites respectively. The exchanges between Mongolia, Tibet and the inland areas were regarded as the internal affairs of the state. North Korea, Japan, Russia and other countries once served as an independent foreign country, under the jurisdiction of the Ministry of etiquette. But in late Qing period, under the western colonial system, the new treaty system gradually replaced the tribute system; the western countries signed treaties with Asian countries and formed the Western-Asia model. The political and economic relations within Asia, especially between China and its neighbors, were hit and affected.

The formation and development of the tribute system was closely inseparable from economic exchanges, and had important relations with political and diplomatic relations. In the strong period of the central Dynasty, the neighboring countries were more easy to convergence in the central Dynasty, the central Dynasty could also be more open, inclusive attitude to the surrounding countries. In the weak period of the central Dynasty, the maintenance of the tributary trading system was relatively weak, subject to external shocks and influences were relatively easy. On the whole, the tribute trade system reflects the interactions between the central Chinese Dynasty and the neighboring countries in economy and politics.

\section{Summary}

In ancient China, most of the foreign trades were dominated by the central Dynasty, which took the initiative to explore the world from the western Han Dynasty, and set up trade channels to communicate with the inland and the sea. To build a diversified tribute trade system, China and neighboring countries established close ties in the economic, political and other aspects. Fundamentally speaking, there were both competition and cooperation between ancient China and neighboring countries. The central Dynasty's policies towards neighboring countries are different in different periods with the changes of the national strength and foreign policies. And peripheral countries also showed a volatile and fluctuant pattern when they faced the central dynasty, no matter of support or confrontation, which not only showed foreign trade relations and pure economic competition, but also the the comprehensive elements of competition and cooperation, with combination of complex elements.

Under the new national environment, when we rethink and measure China's ancient trade relations, we can go through a series of processes such as the construction, expansion, fluctuation and decline of the Silk Road and the tribute system, to observe China's foreign policy and trade in the tradition and characteristics. This also suggests that when we observe China's current foreign policy and solve trade problems, we should conduct a long-term longitudinal study and analysis from the historical point of view. 


\section{References}

[1] John King Faribank, The Chinese World Order: Traditional China's Foreign Relations, Cambridge Mass Harvard University Press, 1968.

[2] Takeshi Hamashita, The International Opportunity of Modern China: Tributary Trade System and Modern Asia, China Social Sciences Press, 1999.

[3] Timothy Brook et al., Sacred Mandates: Asian International Relations since Chinggis Khan, Chicago: University of Chicago Press, 2018.

[4] David Kang, East Asia before the West: Five Centuries of Trade and Tribute, New York: Columbia University Press, 2012

[5] Ge Zhaoguang, Residence in China: Reconstructing the Historical Narration of "China”, Zhong Hua Book Company, 2011.

[6] Nagasawa Kazutoshi, Review and Prospect of Silk Road Research, 1977.

[7] Chen Yan, Brief Research on Maritime Silk Road, Historical Research, 1982(3).

[8] He Fangchuan, Research on "Huayi Order", Journal of Peking University, 1998(06).

[9] Li Xiang, A summary of the development of foreign trade in ancient China, Journal of Finance and Economics, 1988(8).

[10]Quan Hexiu, Commentary on Tributary Relations in Ancient China, China's Borderland History and Geography Studies, 2005(3). 